\title{
Evaluation of the antifungal activity of Ficus bengalensis against Candida albicans; an experimental study
}

\author{
Fernando K. A. B*, Bandara H. M. W. R \\ Department of Kaumarabruthya \& Stree Roga, Gampaha Wickramarachchi Ayurveda Institute, University of Kelaniya, Yakkala, Sri Lanka \\ DOI: 10.29322/IJSRP.10.08.2020.p104128 \\ http://dx.doi.org/10.29322/IJSRP.10.08.2020.p104128
}

\begin{abstract}
Diverse range of bioactive molecules are produced by the plants which making them rich source of different types of medicine. Nowadays, most of the drugs are obtained from natural sources or semi synthetic derivatives of natural products that used in traditional system of medicine. In Ayurvedic treatments, Ficus bengalensis (Vata) plant uses for so many diseases as topical applications and internal medications. Especially, this herbal plant uses in the treatment of fungal infections. This study was conducted to determine the antifungal activity of Ficus bengalensis against the laboratory specimens of Candida albicans. The disc diffusion technique was used to test antifungal sensitivity by using Muller Hinton Agar medium. Fluconazole $2.5 \mathrm{mg} / \mathrm{ml}$ discs were used as controls for comparison with the selected herbal extract. The different concentrated decoctions as sample A, sample B and sample C were prepared by using bark of Ficus bengalensis for determine the antifungal activity comparatively. The mean inhibitory zone diameters of sample A, sample B, sample C and control were $13.1 \mathrm{~mm}, 13.9 \mathrm{~mm}, 18.9$ and $18.6 \mathrm{~mm}$ respectively. Sample $\mathrm{C}$ showed more inhibitory effect than the effect of sample A, sample B and control drug. It could be concluded that Ficus bengalensis has potential effect in the management of infections caused by Candida albicans. The efficacy of the decoction increased with higher concentration and prolonged duration of boiling. Further research is necessary to determine the identity of the antifungal compounds within this plant and also to determine its full spectrum of efficacy.
\end{abstract}

Index Terms- Ficus bengalensis; bark decoctions; Candida albicans; Antifungal effect

\section{INTRODUCTION}

$\mathrm{M}$ ost of the drugs in nowadays are obtained from natural sources or semi synthetic derivatives of natural products that used in the traditional systems of medicine. Thus it is logical approach in drug discovery to screen traditional natural products due to diverse range of bioactive molecules produce by plants which making them rich sources of different type of medicines (Sukanya, Sudesha and Hariprasad, 2010).

Many plant extracts have been used as source of medicinal agents to cure cutaneous infections, urinary tract infections, cervicitis, vaginitis, gastrointestinal disorders, respiratory diseases, helminthic infections, parasitic protozoan diseases and inflammatory processes. Candida albicans is most important among the microbial infections for human vaginitis (Biggs and Williams, 2009).
The infection caused by the Candida albicans is naturally present in the vaginal tract of women. When the concentration of this fungus increases, the several physical symptoms make their appearance which include an uncomfortable condition, itching in the vaginal area, irritation, inflammation of the labia majora, labia minora or perineal area, vaginal discharge, foul vaginal odor, pain or irritation with sexual intercourse. The biological name for this condition is candidiasis. Candida albicans begins to invade and colonize the body tissues. These colonies release powerful chemicals into the blood stream causing such varying symptoms as lethargy, chronic diarrhea, vaginitis, bladder infections, muscle and joint pain, menstrual problems, constipation and severe depression. Sometimes excessive use of antibiotics, birth control pills and steroids will allow candidiasis to become a chronic, systemic infection that cause tissue damage throughout the body. Chemicals produced by the Candida albicans attack the immune system and if the immune system weakens it will spread out into various body tissues and colonize (Dawn, 2003).

According to Ayurveda there are twenty yonivyapad has described. Those are classified as vata, pitta, kapha and thridosaja yonivyapad. Among those yonivyapad, symptoms of kaphaja yonivyapad is similar with Candida albicans infection. Vitiated kapha reaches yoni (vagina) and causes the clinical features of itching with mucoid discharges (Tewari, 2000).

Ficus bengalensis belongs to family Moraceae commonly known as Nuga in Sinhala has been widely used in different types of traditional medicines. Ficus bengalensis is useful in burning sensation, hemoptysis, hemorrhage, diarrhoea, dysentery, diabetes, enuresis, ulcers, skin diseases, gonorrhea, leucorrhoea and hyperpiesia. According to Ayurveda this plant is cold in potency, cure ulcers, cure herpes, reduces burning sensation, increase complexion and cures disease of vagina (Murthy, 2004). The prepared qwatha of Ficus bengalensis bark used for the treatment in Candida albicans vaginal infection (Buddhadasa, 2007).

Objectives of this study were to determine the antibacterial effect of Ficus bengalensis against the laboratory specimen of Candida albicans.

\section{Methodology}

Bark of Ficus bengalensis were collected from the Gampaha District of Sri Lanka. All materials were cleaned by using hot water.

- Preparation of Drug 
The plant extract were prepared as three samples in different decoctions. Sample A was prepared by using $60 \mathrm{~g}$ bark of Ficus bengalensis with $1920 \mathrm{ml}$ of water boiled under moderate heat for 2 hours and obtain $240 \mathrm{ml}$ of decoction. Sample B was prepared by using $60 \mathrm{~g}$ bark of Ficus bengalensis with $1920 \mathrm{ml}$ of water boiled under moderate heat for $21 / 2$ hours and obtain $120 \mathrm{ml}$ of decoction. Sample C was prepared by using $60 \mathrm{~g}$ bark of Ficus bengalensis with $1920 \mathrm{ml}$ of water boiled under moderate heat for 3 hours and obtain $60 \mathrm{ml}$ of decoction.

- Preparation of Sensitivity discs

Whatman No. 1 filter paper was used to prepare sensitivity discs. The sterile discs of $5 \mathrm{~mm}$ in diameter was impregnated with selected herbal extract for 24 hours, and dried in a hot air oven at $60^{\circ} \mathrm{C}$ for 5 minutes and stored in small plastic tubes with silica jell packs.

- Preparation of Inoculum

3-5 colonies of standard strain Candida albicans was suspended in $9 \mathrm{ml}$ of distilled water. The turbidity was adjusted to be visually comparable with $0.5 \mathrm{McF}$ arland standard.

- Preparation of Muller Hinton Agar

Muller Hinton Agar was prepared from a commercially available dehydrated base according to the manufacturer's instructions. It was allowed to cool in a 45 to $50^{\circ} \mathrm{C}$ water bath immediately after autoclaving. Freshly prepared and cooled medium was poured into flat bottomed petri dishes in a horizontal surface to give a uniform depth of approximately $4 \mathrm{~cm}$. This corresponds with 25 to $30 \mathrm{ml}$ for plates that having diameter of $100 \mathrm{~mm}$. The plates were incubated at $37^{\circ} \mathrm{C}$ for 1 hour and allowed to solidifying at room temperature.

- Preparation of control drug

Fluconazole (Pfizer-Roerig, Inc., New York, N.Y.) $2.5 \mathrm{mg} / \mathrm{ml}$ final stock concentrated discs were prepared to use as controls for comparison with the selected herbal extract.

- Preparation of Petridis

Inoculum was spread over the nutrient agar plate with sterile cotton swab in order to obtain uniform microbial growth. Discs were placed in the center of the agar and 10 groups of discs were prepared. The fluconazole $25 \mathrm{mcg}$ discs were used as controls for comparison with the selected herbal extract. The plates were incubated for overnight at $37^{\circ} \mathrm{C}$ and measured the inhibition zone by using normal ruler.

- Interpretation of the zone sizes

The zones size of antimicrobial action was measured by using the interpretative chart that reporting the organisms as 'Resistant', Intermediate sensitivity' and 'Sensitivity' (susceptible).

Zone size for fluconazole $2.5 \mathrm{mg} / \mathrm{ml}$ : Resistant $<14 \mathrm{~mm}$, Susceptible dose dependent $-15 \mathrm{~mm}-18 \mathrm{~mm}$, Sensitive $>19 \mathrm{~mm}$

\section{RESULTS}

Table 1: Inhibitory Zone Diameters in Disc group 01

\begin{tabular}{|c|c|c|c|c|}
\hline Type of disc & Sample A & Sample B & Sample C & Fluconazole \\
& & & & $2.5 \mathrm{mg} / \mathrm{ml}$ \\
\hline Zone diameter $(\mathrm{mm})$ & 12 & 14 & 18 & 18 \\
\hline
\end{tabular}

Table 2: Inhibitory Zone Diameters in Disc group 02

\begin{tabular}{|c|c|c|c|c|}
\hline Type of disc & Sample A & Sample B & Sample C & Fluconazole \\
& & & & $2.5 \mathrm{mg} / \mathrm{ml}$ \\
\hline Zone diameter $(\mathrm{mm})$ & 13 & 15 & 20 & 24 \\
\hline
\end{tabular}

Table 3: Inhibitory Zone Diameters in Disc group 03

\begin{tabular}{|c|c|c|c|c|}
\hline Type of disc & Sample A & Sample B & Sample C & $\begin{array}{c}\text { Fluconazole } \\
2.5 \mathrm{mg} / \mathrm{ml}\end{array}$ \\
\hline Zone diameter $(\mathrm{mm})$ & 10 & 10 & 15 & 13 \\
\hline
\end{tabular}

Table 4: Inhibitory Zone Diameters in Disc group 04

\begin{tabular}{|c|c|c|c|c|}
\hline Type of disc & Sample A & Sample B & Sample C & $\begin{array}{c}\text { Fluconazole } \\
2.5 \mathrm{mg} / \mathrm{ml}\end{array}$ \\
\hline Zone diameter $(\mathrm{mm})$ & 13 & 14 & 18 & 15 \\
\hline
\end{tabular}

Table 5: Inhibitory Zone Diameters in Disc group 05 
International Journal of Scientific and Research Publications, Volume 10, Issue 8, August 2020

ISSN 2250-3153

\begin{tabular}{|c|c|c|c|c|}
\hline Type of disc & Sample A & Sample B & Sample C & $\begin{array}{c}\text { Fluconazole } \\
2.5 \mathrm{mg} / \mathrm{ml}\end{array}$ \\
\hline Zone diameter $(\mathrm{mm})$ & 14 & 14 & 19 & 18 \\
\hline
\end{tabular}

Table 6: Inhibitory Zone Diameters in Disc group 06

\begin{tabular}{|c|c|c|c|c|}
\hline Type of disc & Sample A & Sample B & Sample C & $\begin{array}{c}\text { Fluconazole } \\
2.5 \mathrm{mg} / \mathrm{ml}\end{array}$ \\
\hline Zone diameter $(\mathrm{mm})$ & 14 & 14 & 21 & 20 \\
\hline
\end{tabular}

Table 7: Inhibitory Zone Diameters in Disc group 07

\begin{tabular}{|c|c|c|c|c|}
\hline Type of disc & Sample A & Sample B & Sample C & $\begin{array}{c}\text { Fluconazole } \\
2.5 \mathrm{mg} / \mathrm{ml}\end{array}$ \\
\hline Zone diameter $(\mathrm{mm})$ & 13 & 11 & 15 & 17 \\
\hline
\end{tabular}

Table 8: Inhibitory Zone Diameters in Disc group 08

\begin{tabular}{|c|c|c|c|c|}
\hline Type of disc & Sample A & Sample B & Sample C & $\begin{array}{c}\text { Fluconazole } \\
2.5 \mathrm{mg} / \mathrm{ml}\end{array}$ \\
\hline Zone diameter $(\mathrm{mm})$ & 15 & 17 & 25 & 23 \\
\hline
\end{tabular}

Table 9: Inhibitory Zone Diameters in Disc group 09

\begin{tabular}{|c|c|c|c|c|}
\hline Type of disc & Sample A & Sample B & Sample C & $\begin{array}{c}\text { Fluconazole } \\
2.5 \mathrm{mg} / \mathrm{ml}\end{array}$ \\
\hline Zone diameter $(\mathrm{mm})$ & 14 & 16 & 19 & 20 \\
\hline
\end{tabular}

Table 10: Inhibitory Zone Diameters in Disc group 10

\begin{tabular}{|c|c|c|c|c|}
\hline Type of disc & Sample A & Sample B & Sample C & $\begin{array}{c}\text { Fluconazole } \\
2.5 \mathrm{mg} / \mathrm{ml}\end{array}$ \\
\hline Zone diameter $(\mathrm{mm})$ & 13 & 14 & 19 & 18 \\
\hline
\end{tabular}

Table 11: Mean inhibitory zone diameters of Samples with Fluconazole

\begin{tabular}{|c|c|c|c|c|}
\hline Type of disc & Sample A & Sample B & Sample C & Fluconazole \\
& & & & $2.5 \mathrm{mg} / \mathrm{ml}$ \\
\hline Zone diameter $(\mathrm{mm})$ & 13.1 & 13.9 & 18.9 & 18.6 \\
\hline
\end{tabular}




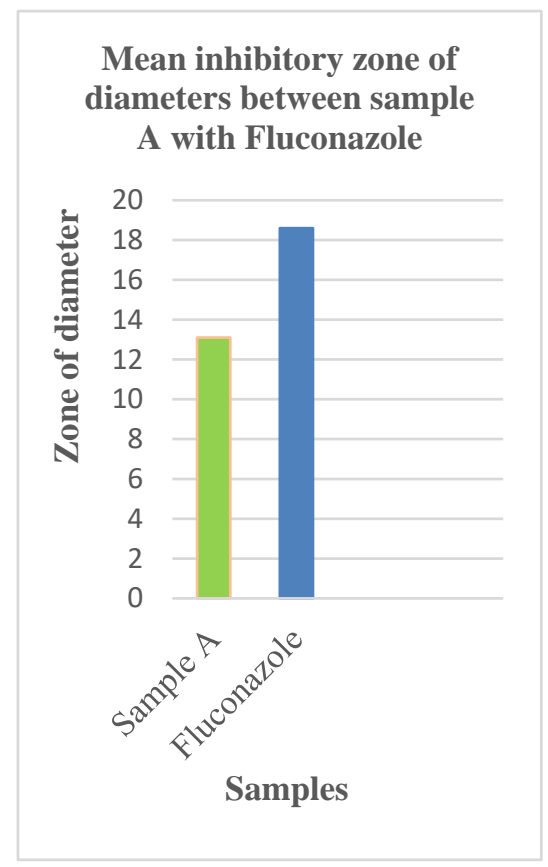

Figure 1: Mean inhibitory zone diameters

of Sample A and Fluconazole

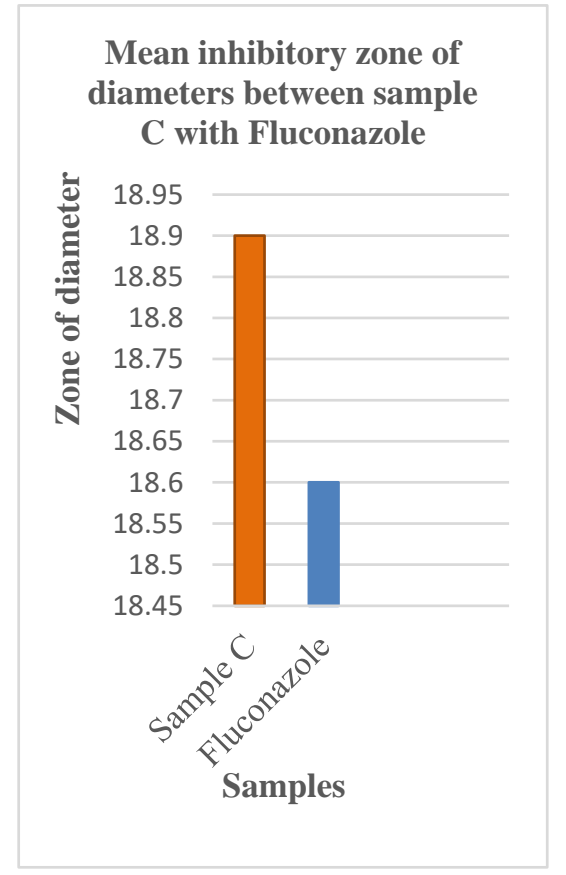

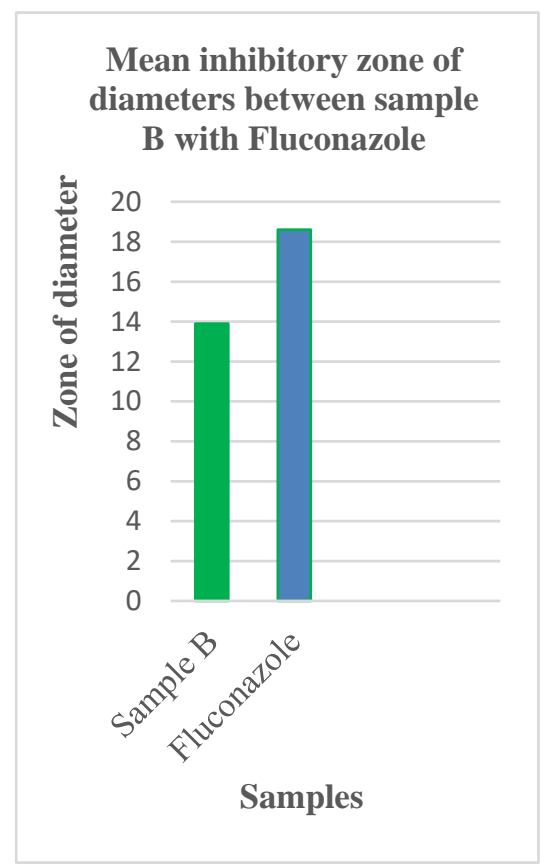

Figure 2: Mean inhibitory zone diameters

of Sample B and Fluconazole

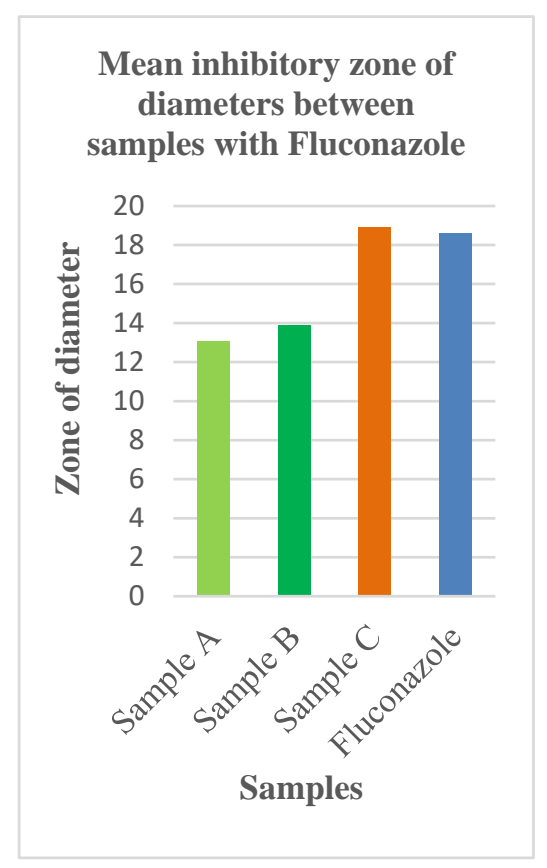

Figure 3: Mean inhibitory zone diameters of Sample C and Fluconazole

Figure 4: Mean inhibitory zone diameters of Sample A, B, C and Fluconazole 


\section{Discussion}

Plant based antifungal compounds have enormous therapeutic potential as they can serve the purpose without any side effects. This study was conducted to determine the antifungal activity of Ficus bengalensis against the laboratory specimens of Candida albicans. The disc diffusion technique was used to test antifungal sensitivity by using Muller Hinton Agar medium. Fluconazole $2.5 \mathrm{mg} / \mathrm{ml}$ concentrated discs were used as controls for comparison with the selected herbal extract. The different concentrated decoctions as sample A, sample B and sample C were prepared by using bark of Ficus bengalensis for comparative determine of the antifungal activity.

Sample A was prepared by using $60 \mathrm{~g}$ bark of Ficus bengalensis and added $1920 \mathrm{ml}$ of water and boiled under moderate heat for 2 hours to obtain $240 \mathrm{ml}$ of decoction. Mean inhibitory zone diameter of Sample A discs had given $13.1 \mathrm{~mm}$. Sample B was prepared by using $60 \mathrm{mg}$ of the bark of Ficus bengalensis and added $1920 \mathrm{ml}$ of water and boiled under moderate heat for 2 and half ours to obtain $120 \mathrm{ml}$ of decoction. Mean inhibitory zone diameter of Sample B discs had given $13.9 \mathrm{~mm}$. Sample C was prepared by using $60 \mathrm{~g}$ of the bark of Ficus bengalensis and added $1920 \mathrm{ml}$ of water and boiled under moderate heat for 3 hours to obtain $60 \mathrm{ml}$ of decoction. Mean inhibitory zone diameter of Sample $\mathrm{C}$ discs had given $18.9 \mathrm{~mm}$. Mean inhibitory zone diameter of $2.5 \mathrm{mg} / \mathrm{ml}$ of fluconazole discs had given $18.6 \mathrm{~mm}$.

It was clear from the present results, that high concentration of decoction of Ficus bengalensis exhibited pronounced activity against the Candida albicans. The results showed that the high concentration of Ficus bengalensis had more inhibitory effect than the other low concentrations. This tends to interpret that the active ingredients of the bark of the Ficus bengalensis is better extracted with adding more water, prolong boiling time and high concentration than others. The results showed sample $\mathrm{C}$ had more inhibitory effect than fluconazole $2.5 \mathrm{mg} / \mathrm{ml}$. It means the efficacy of sample $\mathrm{C}$ is better than fluconazole against Candida albicans. Therefore, decoction of Sample $\mathrm{C}$ can use to treat for Candida albicans infection.

Continued further exploration of plant derived antifungal drugs are needed today. Further research is necessary to determine the identity of the antifungal compounds from within this plant and also to determine its full spectrum of efficacy. However, the present study of in antifungal evaluation of some plants forms a primary platform for further phytochemical and pharmacological studies to discover new antifungal drugs.

\section{CONCLUSION}

Standing on above results it was concluded that Ficus bengalensis has antifungal activity against Candida albicans infection. The efficacy of the decoction increased with higher concentration and prolonged duration of boiling. The efficacy of the Sample C was better than $2.5 \mathrm{mg} / \mathrm{ml}$ of fluconazole. Further research is necessary to determine the identity of the antifungal compounds within plants and also to determine their full spectrum of efficacy. However, the present study of in vitro antifungal evaluation of some plants forms a primary platform for phytochemical and pharmacological studies to discover new antibiotic drugs.

\section{REFERENCES}

[1] Rahman A. U., and Choudhary M. I., Diterpenoid and steroidal alkaloids Nat. Prod. Rep. 1995; 12:361-379.

[2] Biggs W. S., Williams RM. 2009, Common gynecologic infections. Prime Care. Mar; 36(1):33-51.

[3] Brownlee H. E., McEuen A. R., Hedger J and Scott M., Antifungal effect of cocoa tannin on the witches' broom pathogen Ficus bengalensis. Physiol. Mol. Plant Pathol. 1990; 36:39-48.

[4] Buddhadasa R, Charaka Samhitha, Chikitsa Sthana, Sinhala translation, 1st edition, Department of state language, Colombo, 2007; p 812.

[5] Dawn C.S., Textbook of Gynecology, Contraception \& Demography, 14th edition, Dawn Books, Kolkata, 2003.

[6] Kubo I., Muroi H. and Himejima M., Combination effects of antifungal nagilactones aginst Candida albicans and two other fungi with phenylpropanoids. J. Nat. Prod. 1993; 56:220-226.

[7] Meyer J. J. M., Afolayan A. J., Taylor M. B. and Erasmus D, Antifungal activity of galangin from the aerial parts of Ficus bengalensis. J. Ethnopharmacol. 1997; 56:165-169.

[8] Murthy K. R. S., Bhavaprakasha of Bhavamsra, Vol 1, Chowkhamba Krishnadas Acadamy, Chowkhamba press, Varanasi, 2004.

[9] Peres M. T. L. P., Monache F. D., Cruz A. B., Pizzolatti M. G. and Yunes R. A., Chemical composition and antimicrobial activity of Ficus bengalensis. Baillon. J. Ethnopharmacol. 1997; 56:223-226.

[10] Sukanya S. L. J., Sudesha P., Hariprasad S. R., Niranjana H. S., Prakash and Fathima S. K., 2010, Antimicrobial activity of leaf extracts of Indian medicinal plants against clinical and phytopathogenic bacteria. Department of studies in Applied Botany, Seedpathology and Biotechnology, University of Mysore, Manasagangotri, Kamataka India- 570006.

[11] Tewari P., Prasutitantra Evam Stri Roga, Vol II, 2nd edition, Chukhambha Orientalia, Varanasi, 2000; p 252-266.

\section{AUTHORS}

Correspondence Author - Dr. K. A. B. Fernando, Demonstrator (Temporary), Department of Kawmarabruthya \& Stree Roga, Gampaha Wickramarachchi Ayurveda Institute, University of Kelaniya, Sri Lanka.

E mail - baddrafernando@gmail.com Contact number - +94 715997966

Second Author - Dr. H. M. W. R. Bandara, Lecturer

(Temporary), Department of Kawmarabruthya \& Stree Roga, Gampaha Wickramarachchi Ayurveda Institute, University of Kelaniya, Sri Lanka.

Email - wbandara10@gmail.com

Contact number -+94 
